\title{
Livia Marin: Sobre objetos, citas y apropiaciones en el arte chileno contemporáneo ${ }^{1}$
}

\section{Livia Marin: On borrowings, appropriations and objects in Chilean Contemporary Art}

\author{
Claudia Campaña \\ Pontificia Universidad Católica de Chile, Chile \\ ccampana@uc.cl
}

- Resumen - Este escrito es producto de una investigación en el campo de la teoría e historia del arte cuyo objetivo es documentar y analizar una selección de trabajos de Livia Marin (n.1973), artista visual chilena, actualmente radicada en Londres, quien, en su producción de obra, explora las posibilidades estético-expresivas de objetos cotidianos y, en los últimos cuatro años, el recurso de la cita y la apropiación.

Palabras clave: Livia Marin, cita, apropiación, objetos, porcelana.

Abstract - This investigative study, in the field of Theory and Art History, aims to document and analyse selective output of Livia Marin (b.1973), a Chilean visual artist, currently based in London. She explores the esthetic-expressive promise of everyday objects, and over the past four years has also resorted to borrowing and appropriating references.

Keywords: Livia Marin, quote, appropiation, objects, china.

1 Esta investigación fue posible gracias a los fondos obtenidos al adjudicarse el Concurso de Creación y Cultura 2011 convocado por la Vicerrectoría de Investigación y la Dirección de Arte y Cultura (VRI/DAC) de la Pontificia Universidad Católica de Chile. 
Que cada hombre construya su propia catedral. ¿Para qué vivir de obras de arte ajenas y antiguas?

José Luis Borges

La tecnología ha democratizado los viajes y el arte. Un buen número de creadores circula hoy por todo el mundo sin mayor dificultad; las becas, las pasantías y todo tipo de intercambios se multiplican, lo mismo que las ferias y bienales. En Chile aumenta, año tras año, el número de estudiantes de Arte que, una vez titulados, esperan conseguir financiamiento para inscribirse en alguna universidad madrileña, barcelonesa, londinense, parisina o neoyorquina (no sé si en ese orden de prioridades) para perfeccionarse e, idealmente, lograr validación e inscripción internacional. Al residir en el extranjero buscan también estar cerca de obras originales pues, obviamente, estamos geográficamente lejos de los museos y las galerías que conservan y administran los grandes patrimonios visuales de la humanidad. Internet permite un recorrido virtual por algunas salas de estas prestigiosas instituciones, pero nada se compara con la experiencia de estar in situ frente a un original. "Nadie pudo imaginar que los museos se convertirían al final del siglo $\mathrm{xx}$ en santuarios y espectáculos tanto para creadores como para público en general, ofreciendo al turista un equivalente a las rutas de peregrinación medievales, esas que se transitaban para cumplir rituales cargados de devoción», señala Robert Rosemblum, profesor de la Universidad de Nueva York $(13)^{2}$. Su comentario adquiere especial significado si se vive en Chile, pues un artista del Cono Sur generalmente hace un gran esfuerzo para viajar, contemplar e impregnarse de esa suerte de fuerza positiva que, se dice, emana de las obras maestras. En la actualidad casi todo se expone, los espacios museales proliferan, los hay para todos los gustos y quienes más se benefician de ello son precisamente los artistas; tienen, además, acceso a todo tipo de imágenes y publicaciones (impresas y virtuales), de tal modo que las obras del pasado son más accesibles para ellos que para sus antecesores.

La obsolescencia es propia de las ciencias naturales o físicas y no de las humanidades, por lo cual un sinnúmero de artistas visuales contemporáneos ha convertido la historia del arte en su materia prima, sintiéndose, muchos de ellos, motivados a trabajar «a partir de», «después de», «según» o «de acuerdo a». Hace ya tiempo que los paradigmas de la modernidad entraron en crisis y que se validaron los recursos de la cita y la apropiación. Así, por ejemplo, los iconos del renacimiento, del barroco, del rococó, del neoclasicismo y de muchos otros períodos se revisitan y se estudian para después modificarlos, desarticularlos y resignificarlos. Ahora, no toda cita ni toda apropiación de imágenes del pasado, como señala Martín Prada (41), se producen en función de una intención crítica

2 La traducción es mía, la cita textual reza: «[...] who could ever have guessed that, by the end of the twentieth century, museums would become the equivalent of shrines and spectacles for both artists and the general public, providing for modern tourists the equivalent of medieval pilgrimage routes to be visited with ritual devotion?". 
de relectura o desplazamiento sino que muchas, simplemente, ocurren en función de la celebración de su disponibilidad como imagen.

Livia Marin Firmani (n.1973) pertenece a ese grupo de artistas chilenos nómades -aunque no desarraigados-, sensibles y atentos a la tradición. Mientras escribo este ensayo ella vive en Londres, ciudad a donde se traslada en 2005 (gracias a una Beca Presidente de la República y otra de Fundación Andes) para cursar estudios de postgrado en Goldsmiths College, University of London, obteniendo recién en marzo de este año (2012) su Ph.D en Visual Arts.

Desde el 2000 no ha cesado de mirar, seleccionar, recolectar, comprar y modificar artículos de uso diario. El suyo es un continuo ejercicio de exploración del potencial estético-expresivo de esos objetos marcadamente cotidianos que tenemos a la mano. En su taller siempre está rodeada de ellos y, cual alquimista, pasa día tras día elucubrando cómo convertirlos en objetos artísticos. Ya radicada en Londres, al mismo tiempo que recorre con entusiasmo los mercados de pulgas en busca de cerámicas y porcelanas, comienza a investigar, metódicamente, sobre esquemas pictóricos barrocos y diseños de loza del siglo XVIII. Consciente de que no se exige ya una renovación radical al artista desde la posmodernidad y que, por el contrario, se le permite la memoria y la posibilidad de citar y apropiarse de lenguajes visuales de otros, es que Marin, sin la obligación de innovar y comenzar siempre de fojas cero -y sin pudor ni culpa- se anima a estudiar las magníficas colecciones del British Museum y de la National Gallery, como también aquellas del Victoria and Albert Museum y de la Wallace Collection, entre otras. Por ahora ha decidido entablar un diálogo con otros autores (pasado y presente) y se ha permitido parafrasear, ayudando así a poner nuevamente en circulación y a repensar lo que anteriormente hicieron y crearon otros. No es nada extraño que, estando en Inglaterra, haya optado por incorporar guiños a la tradición visual en su trabajo pues, si de algo saben los ingleses, es de tradiciones.

En Goldsmiths (institución fundada en 1891 originalmente para formar orfebres y artesanos y adquirida en 1904 por la Universidad de Londres) se estimula el trabajo de taller, la lectura, la participación en seminarios y se incentiva a los alumnos a exponer(se) fuera de los muros del campus. En los últimos años, por tanto, Livia Marin ha trabajado sin pausa y el producto de su esfuerzo se traduce tanto en la obtención de su grado académico de doctor como en la participación de varias muestras individuales y colectivas, a saber: 1) El lugar de lo invisible, Sala Gasco, Santiago de Chile (2009); 2) Broken Things, House of Propellers, Londres (2009); 3) Nature Morte, House of Propellers, Londres (2010); 4) Sutura, Galería Eduardo Fernandes, Sao Paulo (2011); 5) The Missing Willow, Saatchi Gallery, en el contexto de la muestra Tectonic Shift: Contemporary Art from Chile, Londres (2011); 6) Untitled (Objet Dada), Edel Assanti, en el contexto de la muestra Objet Dada, Londres (2011); 7) Broken Willow, Devon Guild, en el contexto de la muestra Blue, Devon (2012) 8) Trading Routes (2012) en el contexto de la muestra Nuestro sitio, MAC Niteroi, Brasil y 9) Nomad Patterns, Eagle Gallery, Londres (2012). A 
continuación, el comentario y el análisis de una selección de obras expuestas en algunos de los espacios anteriormente mencionados.

\section{LA VISIBILIZACIÓN DE TERRITORIOS Y OBJETOS COTIDIANOS}

¿Por qué Livia Marín se ha dedicado a investigar sobre los patrones de la porcelana china e inglesa en vez de concentrarse en la cerámica de Quinchamalí o Pomaire? ¿Por qué le obsesionan las cosas quebradas y la loza en especial? Parto por intentar una respuesta a esta última interrogante y recuerdo una anécdota que ella misma me relató, advirtiendo que resulta útil considerarla al momento de analizar sus trabajos de los últimos cuatro años. Soy historiadora del arte y, acaso por formación o deformación profesional, disfruto reconstruyendo historias. En una de nuestras tantas conversaciones, se me ocurrió preguntar a Livia dónde estaba la tarde del 3 de marzo de 1985 a las 19:47 horas, cuando un sismo de 7,8 grados en la escala de Richter remeció las regiones Cuarta, Quinta, Sexta y la Metropolitana en la Zona Central del país. El epicentro se localizó en el mar, entre Valparaíso y Algarrobo, a unos $20 \mathrm{~km}$ de la costa y a $15 \mathrm{~km}$ de profundidad. Las cifras oficiales indican que 177 personas murieron, 2.575 resultaron heridas y 979.792 damnificadas, registrándose, además, numerosos y considerables daños en la infraestructura de las localidades afectadas. Livia Marin confiesa que no sintió con particular intensidad el terremoto pues, pese a estar en Santiago, se encontraba dentro de un auto. Sin embargo, constató lo grave de la situación al arribar una hora después al departamento del séptimo piso donde vivía junto a sus padres, cuya puerta de ingreso estaba bloqueada por un mueble. Relata que fue una odisea entrar y que, cuando lo lograron, se dirigió de inmediato a su pieza para ver su colección de figuritas de cerámica que diversos laboratorios médicos habían regalado a sus padres; las encontró desperdigadas en el suelo y la gran mayoría rota. En el living, en tanto, estaban también quebrados los jarrones chinos que coleccionaba su madre, a quien recuerda recogiéndolos pedazo por pedazo, cada trocito, aun el más ínfimo. Tenía doce años y pensó: "¿Para qué guarda hasta la última astilla?», aunque tiempo después lo comprendió, cuando fueron restaurados y volvieron a ocupar su lugar. "Cuando comencé a trabajar en mi serie Broken Things, se me vinieron a la memoria esas imágenes de pérdida y recuperación del terremoto de $1985 »^{3}$.

La serie Broken Things a la cual se refiere la artista se expuso inicialmente en Santiago de Chile en Sala Gasco Arte Contemporáneo entre el 8 de junio y 24 de julio de 2009, en el contexto de El lugar de lo invisible, una muestra bipersonal que realizó junto a Magdalena Atria y que, ese mismo año, expuso posteriormente en Londres. En Santiago, Marin presentó dos trabajos: Cosas rotas I y II, obras que siguen, entre otras, las huellas del proyecto objetualista de Marcel Duchamp y que son el inicio de su investigación sobre objetos rotos.

\footnotetext{
Campaña, en entrevista con la artista, 3 de diciembre de 2011 en Santiago de Chile.
} 


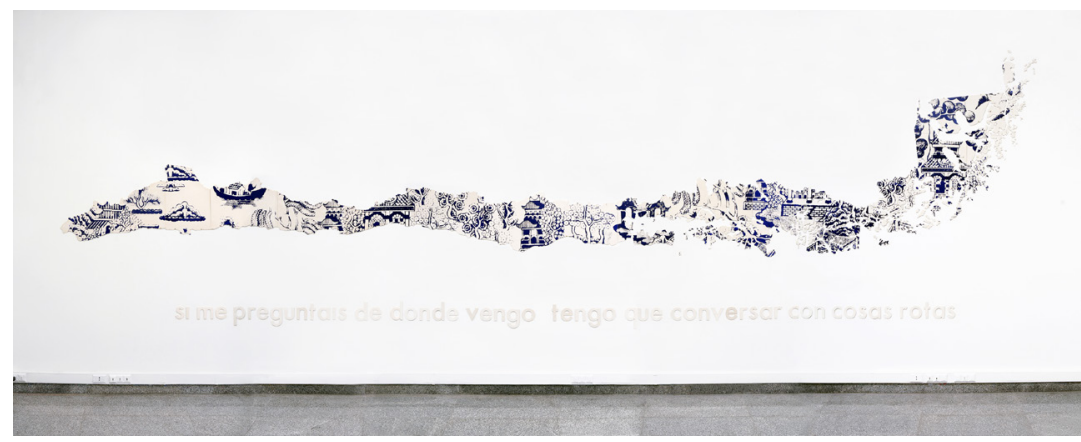

Figura 1. Livia Marin. Cosas rotas I, 2009.

Serigrafía sobre yeso, $900 \times 280 \times 0.5 \mathrm{~cm}$

Sala Gasco, Santiago

Gentileza Livia Marin

Foto: Vinka Quintana

La exposición en Gasco: al ingresar, lo más conspicuo era un gran mapa geográfico de Chile de 900 × 280 × 0,5 cm colgado de manera horizontal en el muro principal de la sala que a ella le correspondía ocupar (Figura 1). Los mapas en el muro no tienen nada de particular, al contrario, por siglos se han enmarcado y destinado a la decoración de habitaciones. Pero este no tenía marco, ni estaba impreso en papel o género, sino confeccionado con una sumatoria de piezas de yeso. Se asume que los mapas son imágenes de mediciones objetivas de un determinado lugar geográfico pero, como advierte David Woodward, son también ventanas al mundo, cuya forma y posición, y la vista que permiten, las decide quien los diseña (cit. en Jackson 16). Según lo anterior, cabe preguntar: ¿qué visión -qué panorámica- ofrecía Marin a través de su mapa? Suspendido en el muro de una galería de arte, era soporte y lugar de encuentro de diversos discursos, problemas y geografías: visuales, biográficos y políticos, entre otros. Para empezar, constituía un guiño al formato apaisado tan propio del género pictórico del paisaje y, a la vez, una clara alusión al arte de la cartografía, una obvia referencia a nuestro territorio, al país donde se exponía y a la nacionalidad de su autora. Lo primero que recordé al verlo fue Britain seen from the North, la obra de Tony Cragg de 1981; aunque Marin me comentó que no la conocía al momento de hacer su instalación. Lo que sí había estudiado atentamente eran los trabajos de Mona Hatoum (Beirut, 1952), en especial aquellos donde la destacada artista libanesa -hoy también residente en Londres- toma imágenes cartográficas para dotarlas de connotaciones poético-políticas. En el año 2010, Hatoum declaró al diario El País: «He hecho muchos mapas y creo que es porque te dan una tremenda sensación de inestabilidad», añadiendo que, «los mapas son abstracciones del espacio y es fascinante cómo cada persona es capaz de proyectarse dentro de un mapa» (véase Fietta Jarque). Livia Marin conoció la obra de esta artista en 1999 gracias a Eugenio Dittborn (Premio Nacional de Arte 2005), quien fue profesor suyo en el Magíster de la Universidad de Chile. Como sucede con otras propuestas de Marin, en Cosas rotas I la deuda con Mona Hatoum es evidente. 


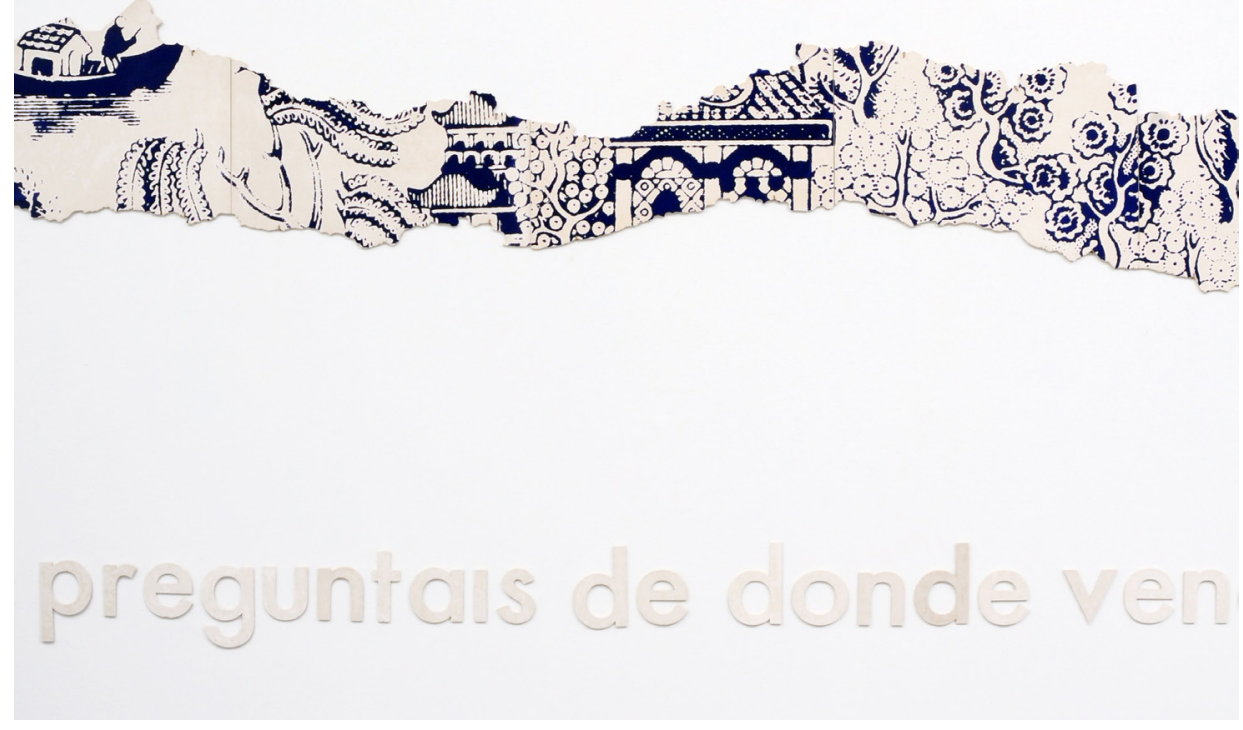

Figura 2. Livia Marin. Detalle, Cosas rotas I, 2009.

Gentileza de Livia Marin. Foto: Vinka Quintana

«Los artistas no crean en un vacío. Están continuamente estimulados por otros artistas y por las tradiciones artísticas del pasado [...] Es la tierra de [sic] donde crecen y de la que se alimentan. [...] Los artistas más grandes y más originales, incluso los más sorprendentes innovadores, son profundamente sensibles a la tradición» (Woodford 75). Lo anterior es irrefutable, por lo que, además del vínculo con la obra de Hatoum, la visión del mapa de Livia Marin permitía establecer otras asociaciones e identificar otros parentescos visuales. Había, por ejemplo, omitido adrede toda información topográfica, borrado toda coordenada de la superficie para colocar en su lugar fragmentos de un patrón propio de la porcelana. De seguro que la mayoría de los visitantes a la muestra lo asociaron con un diseño de la cerámica china, y solo quienes conocen un poco más del tema habrán identificado el Blue Willow (sauce azul) diseñado por Thomas Minton (c.1780); típico patrón de la loza inglesa, aunque, claro está, este es inequívocamente derivativo de la producción china (Figura 2). 


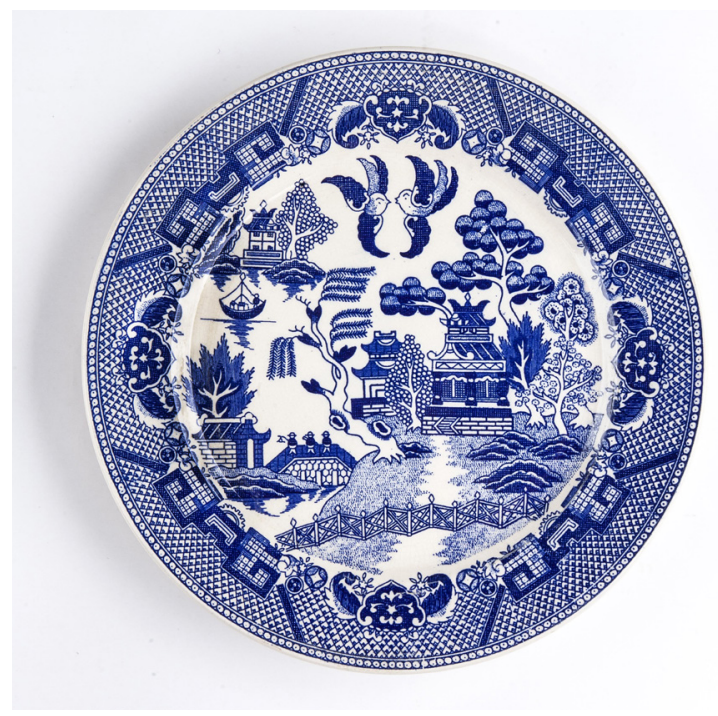

Figura 3. Plato bajo cerámico con calcomanía, adaptación actual del diseño Blue Willow de Thomas Minton. Foto: Pin Campaña

Valga un poco de historia: la porcelana fue manufacturada por primera vez a fines del siglo xI, y China monopolizó su producción por centurias. Las cerámicas de Oriente eran muy apreciadas en Occidente pues durante siglos los europeos fueron incapaces de resolver problemas técnicos asociados a su fabricación, consiguiéndolo recién en 1709. Los primeros esfuerzos por imitar la porcelana china ocurrieron en Florencia durante el Renacimiento gracias al entusiasmo de los Médici, en tanto que la importación de grandes cantidades comenzó cuando los navegantes portugueses llegaron a China en 1513, según comenta Rose Kerr (Encounters 47). Es este el inicio de un rentable negocio que derivó en moda. Un dato más: fue durante el siglo XVII que las fábricas europeas comenzaron a imitar las cerámicas traídas de Oriente, pero más relevante aún es que empezaron a producir diseños para la clientela local. Por ende, lo que hizo Thomas Minton en el siglo XviıI (en pleno rococó) fue crear un dibujo para el mercado inglés «al estilo chino». Su creación fue pura idealización y fantasía, pues intentó evocar el espíritu de aquellos paisajes del Lejano Oriente que él nunca visitó. Su diseño, no obstante, alcanzó tal aceptación y popularidad que su Willow Pattern ha sido usado por siglos para decorar buena parte de la vajilla utilizada en Inglaterra, actualmente exportada e imitada urbi et orbi (Figura 3). Nada más común y corriente que servir los alimentos en el Londres de hoy sobre loza impresa con el famoso Blue Willow de Minton.

¿Pero por qué le atrajo a Marin esta trama y no otra? Ella explica que cuando le hablaron del Willow Pattern, estando ya en Londres, le fascinó su historia, su origen híbrido y la opacidad de su identidad cultural, el cómo se plasman en este diseño las ideas y visiones de Occidente sobre ese Oriente «otro». Le atrajo cómo la 
ficción, plasmada en un paisaje chinesco, llega a la mesa de muchos -primero a una elite y después a todo público- y la tensión entre original y copia que se desarrolla en la trama misma. A dicha tensión y/o patrón se acercó por dos vías: visitando la extraordinaria colección de cerámicas del Victoria \& Albert Museum y recorriendo los Car Boot Sales (mercados de las pulgas). En estos últimos compró reproducciones sueltas de las piezas fabricadas para la aristocracia -loza impresa con el Willow Pattern-, a partir de las cuales armó una especia de «colección pobre».

Al cubrir la superficie de su mapa con el Willow Pattern, Marin hace una demostración de reconocimiento al exitoso diseño de Minton. Pero su inclusión es también un gesto de apropiación, y acaso también de nostalgia, un recuerdo de su infancia, la cual -ahora sabemos- estuvo acompañada de porcelanas chinas. Hasta se podría especular que al imprimir el patrón sobre su mapa intenta un comentario irónico sobre el Chile actual, ese que está invadido de Norte a Sur por productos made in China.

El diseño azul cobalto se desplegaba a lo largo y ancho del territorio nacional, e incluía pagodas, un bote con una solitaria figura (navegando ahora por nuestro Norte), vallas enrejadas, naranjos y, por supuesto, un sauce. Sin embargo, la característica pareja de palomas en el cielo del diseño de Minton no se encontraba en «región» alguna. ¿Por qué esta omisión? Livia Marin me explicó que no fue intencional -en el sentido de haber seleccionado únicamente algunos motivos de la ilustración- sino que se trató más de un ejercicio de superposición. En él se hizo calzar la trama -estructurada fundamentalmente en base a la forma redonda u ovalada de un plato de cerámica-, con el ancho / largo del mapa hasta cubrirlo totalmente, de manera tal que la superposición del Blue Willow sobre la superficie no alteró ni su forma ni la composición del patrón y, tal como señala la artista, si algunos elementos quedaron inevitablemente fuera del mapa, no están ausentes.

Las peculiaridades de la geografía del suelo chileno se prestaban indudablemente para trabajar en esta obra problemas relativos a la estética del fragmento, la fractura y el deterioro. "Las cosas rotas" se hacían evidentes al contemplar la sección correspondiente al Sur del país, pues las islas e islotes del extremo del mapa se tornaban a ratos cuerpo o materia en proceso de desintegración. En instantes, semejaban piezas de un puzzle aún sin ensamblar y, por ende, todavía sin solucionar. El mapa adoptaba incluso el aspecto de una pintura en ruina; era como contemplar un mural añoso, de esos que invitan a adivinar y a reconstruir mentalmente las partes que se han perdido y/o dañado con el tiempo. Marin advierte: «Esto juega en parte con la geografía natural y fragmentada del sur de Chile y con la fragilidad y movilidad de la lógica maleable que va definiendo territorios» ${ }^{4}$.

A propósito de fragmentos y cosas rotas: bajo el mapa, la artista había colocado una evocadora frase confeccionada igualmente en yeso -por ende, en relieve-. Advierto que las letras no contenían una pizca de azul y no servían como soporte

4 Campaña. Entrevista a la artista vía web, 18 de marzo de 2012. 
a patrón cerámico alguno, por lo cual no se recortaban contra el muro, por el contrario, su color crema se mimetizaba con aquel de la pared. La frase, que por su ubicación «subrayaba» el mapa y acentuaba su horizontalidad (Figura 1), rezaba: «Si me preguntáis de dónde vengo tengo que conversar con cosas rotas». En esta ocasión, Marin recurría a una cita literaria, apropiándose de un verso de Pablo Neruda contenido en el soneto "No hay olvido" del libro Residencia en la Tierra (que se publicara de forma íntegra en Madrid en 1935). Dice le encantó el primer verso «Si me preguntáis de dónde vengo, tengo que decir, Sucede»; la sedujo especialmente la palabra "sucede», y recuerda con nitidez una clase de Carlos Pérez en el Magíster de la Universidad de Chile, año 2000 ó 2001, donde se discutió sobre la profundidad y la ambivalencia contenida en dicha palabra:

En el contexto de mi trabajo, me interesa la dualidad que dicha ambivalencia acarrea: 'sucede' puede connotar una gravedad casi existencial como también el pasar, la coincidencia, la banalidad que necesariamente forma parte de nuestro día-día. Quizás se podría decir que contingencia y necesidad se enredan en la expresión poética 'sucede’s.

Ahora, «si me preguntáis de dónde vengo, tengo que conversar con cosas rotas», indudablemente se relacionaba mejor con esta obra destinada, entre otros propósitos, a explorar la noción de pérdida y su sentido. El verso nerudiano, lleno de energía y fuerza metafísica, funcionaba como activador de asociaciones poéticohistórico-visuales e interactuaba con la propuesta visual; interesantemente, también daba luces sobre la biografía de la autora.

Cuando se llevó a cabo la exposición de Gasco, Livia Marin estaba hace rato instalada en Londres, donde le preguntaban constantemente por su origen; propongo que en Cosas rotas I intentó una respuesta. A través de su obra-mapa parecía explicar al espectador que la mayor parte de su residencia en la tierra ha transcurrido en suelo chileno; informaba que no olvida su sísmico país de origen, lugar donde se rompieron las cerámicas que coleccionaba en su infancia y donde, el mismo año de su nacimiento (1973), se derrumbaron las tradiciones republicanas. En estricto rigor, tengo que conversar con cosas rotas hacía referencia a alguien que pretende comunicarse a través de objetos quebrados, si bien la frase es, obviamente, una rica metáfora para aludir tanto a vidas destruidas y a geografías telúricas, como a conflictos personales. Más allá de la metáfora, del sutil lamento, se debe reconocer que dicho verso era una perfecta bisagra, un vínculo entre un trabajo y otro, pues Cosas rotas I y II se expusieron en la misma sala.

5 Campaña. Entrevista a la artista vía web, 21 de junio de 2012. 


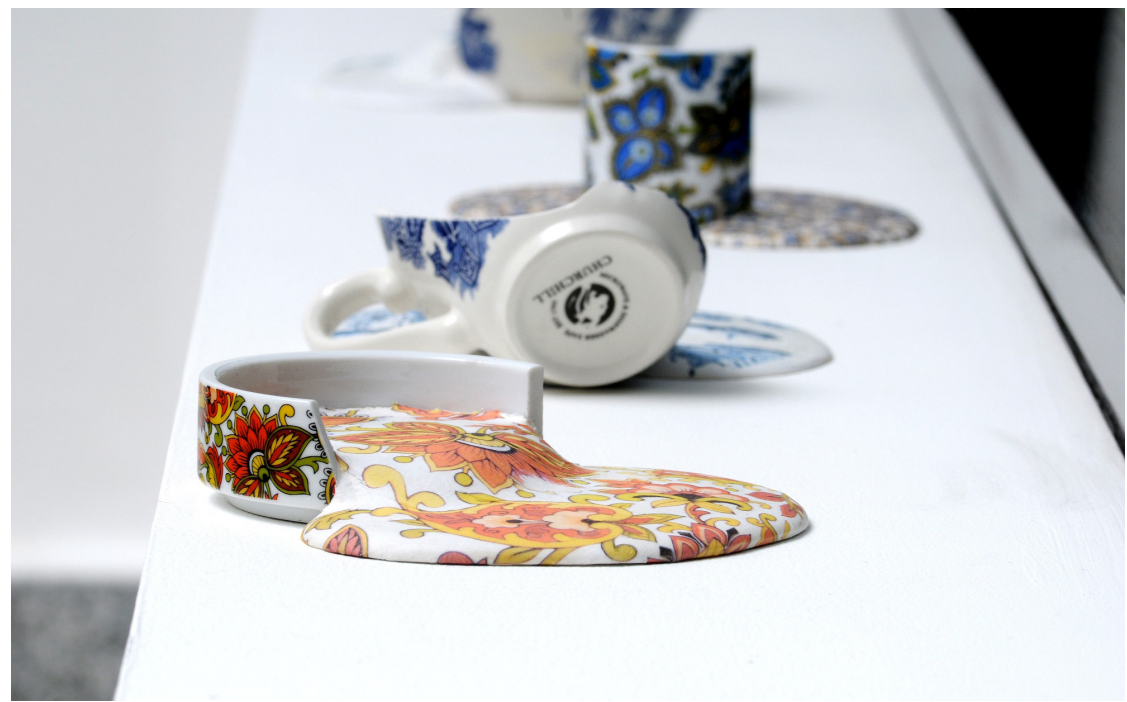

Figura 4. Livia Marin. Detalle, Cosas rotas II, 2009.

Grupo de 40 objetos dispuestos sobre una estructura de $60 \times 102.5 \times 25 \mathrm{~cm}$

Objetos de cerámica, yeso, calcomanía cerámica y papel.

Gentileza Livia Marin

Foto: Vinka Quintana

Enfrente del muro donde colgaba el mapa había grandes ventanales sobre un grueso zócalo que Marin decidió utilizar y reforzar como plinto. Instaló allí Cosas rotas II (Broken Things II), una curiosa selección de objetos artísticos dispuestos en hilera que se parecían al objeto original, o sea, tazas, platos y cremeros con patrones florales archiconocidos, entre los cuales se apreciaba, una vez más, el famoso Blue Willow (Figura 4). Lo particularmente atractivo de esta «colección» de piezas era que todas parecían estar cambiando de estado: de sólido a líquido. Era como si tazas y recipientes hubiesen sido sometidos a altas temperaturas o como si el material no hubiese resistido el agua hirviendo; el espectador era testigo de una metamorfosis, de un simulacro de un proceso de derretimiento. La loza ya no podía contener líquido alguno, en tanto no conservaba su forma original. Los objetos y sus estampados florales aparentaban fluir y derramarse sobre la superficie / mesa / zócalo / plinto. La deformidad objetual recordaba la pintura de Salvador Dalí conocida como Persistencia de la memoria o Los relojes blandos (1931), pues la reblandecida loza, al igual que los relojes dalinianos, parodiaba el determinismo utilitario de los objetos, aunque el proceso de metamorfosis de estas piezas blandas acaso era también reminiscente de los soft objects de Claes Oldenburg (n.1929). A diferencia de los objetos del escultor sueco, los de Marin mantenían su escala, pero en los de ambos se observaba una descontextualización objetual y se ponían en tensión problemas relativos a estructura, material, forma y función. 
Es insólito ver «vajilla derretida», y como lo blando es sinónimo de dócil, pasivo y fofo, se puede afirmar que la propuesta visual contenía un dejo de humor, una aproximación al divertimento. Por la alusión a la suave materialidad de la porcelana, por el interés en el objeto pequeño, porque los patrones florales -asociados a lo femenino- aparecían por todas partes, por los préstamos orientalizantes y por su carácter lúdico, entre otros rasgos, se me antoja también ver en ella ecos de la estética rococó. A propósito de lúdico: al «derretirse» las tazas formaban una poza que se convertía en "plato», completándose visualmente «el juego». Acerca de ello, Livia Marin hace notar que la unión de un fragmento de objeto (taza / recipiente) con una forma abstracta (fluido) resulta en un otro objeto que aparece paradójicamente roto y completo al mismo tiempo. Hace también hincapié en su intención de desorientar al espectador, ofreciéndole un «[...] tercer objeto indeterminado que pareciera estar suspendido entre su formación y su disolución» (Marin, El objeto y su manifestación 17). Y, si bien mustios, los lúdicos objetos seguían siendo perfectamente reconocibles y asociables al ámbito doméstico; a la cocina, que hoy no es solo territorio femenino; aunque, desde tiempos inmemoriales, un florero, una taza o un contenedor simbolizan una matriz, el principio femenino receptivo (apenas hace falta recordar, pero la autora de este trabajo es mujer).

\section{NATURALEZA «HERIDA»: ACTOS DE FRACTURA Y REPARACIÓN}

La obsesión de Marin por los objetos de porcelana no se agotó en la muestra de Sala Gasco. Durante el 2010 se preguntó qué ocurre cuando un objeto se rompe y pierde su capacidad de funcionar: "¿Lo desechamos, lo guardamos, le damos otra función, lo reparamos, lo reemplazamos?» (Marin, «En torno a cosas rotas»16). Entre otras, dichas interrogantes dieron vida a un nuevo cuerpo de obras que presentó en dos exposiciones, Nature Morte (2010) y Sutura (2011); la primera ocurrió en una pequeña sala londinense conocida como House of Propellers (Figura 5) y la segunda en la Galeria Eduardo Fernandes de Sao Paulo. En síntesis, Marin dejó de lado aquí lo volumétrico para concentrarse y dar protagonismo a lo bidimensional. En ambos espacios expuso fotografías de objetos cerámicos, las que rasgó y luego «recompuso» por medio de una costura con hilos de oro, parodiando así las tradicionales técnicas orientales de restauración. Su gesto iconoclasta y la posterior enmienda constituían la obra en sí. Se puede considerar este el segundo capítulo de su investigación en torno a la precariedad objetual. 


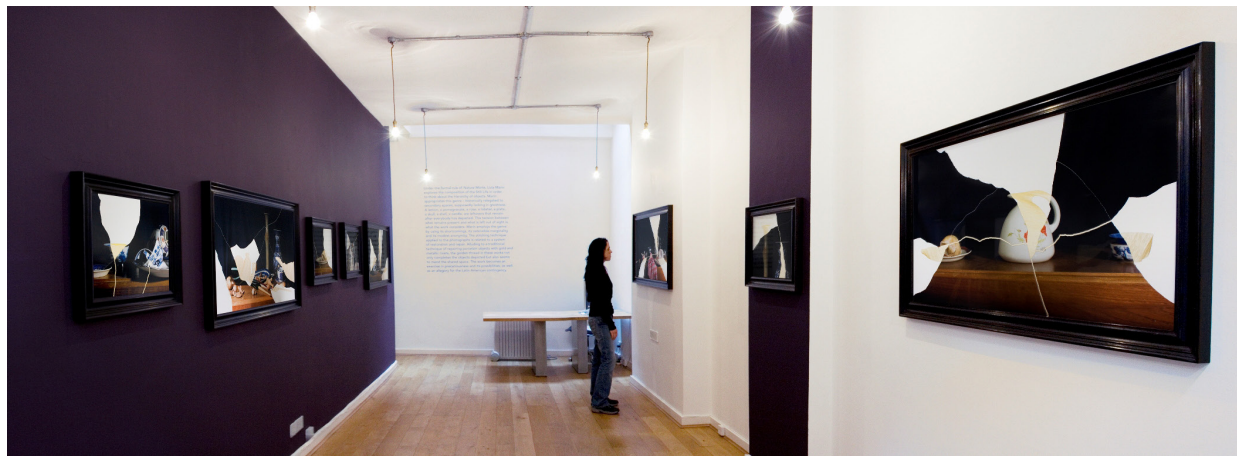

Figura 5. Vista general exposición Nature morte de Livia Marin, 2010.

House of Propellers, Londres

Gentileza de Livia Marin

Fotografía: Sachiyo Nishimura

En Nature Morte Marin reunió ocho obras (cuatro piezas de 62,2 x 109,5 cm y otras cuatro de $39,8 \times 49,8 \mathrm{~cm}$ ) donde, al mismo tiempo que las cuestionaba, adhería a las convenciones de un género pictórico como la naturaleza muerta (Figura 6); entiéndase por éste el de "aquellas obras en las cuales deliberadamente se ha omitido la figura humana, reduciéndose al mínimo los aspectos narrativos para dejar protagonismo al objeto cotidiano y a todo tipo de alimentos dispuestos de múltiples maneras» (Campaña 10). Comenzando por el título de su muestra, en esta serie se le antojó a Marin jugar con el término «naturaleza muerta»; ello pues, a pesar de vivir en Londres, no usó el vocablo inglés still life (naturaleza quieta), sino que prefirió el más dramático rótulo francés: nature morte. En su elección me parece ver un guiño al origen del término; a partir del siglo Xvir se usaban en Holanda dos vocablos para referirse a los cuadros que representaban objetos relacionados con la comida y la cocina: stilleven (léase como "modelos inertes» o "naturalezas inmóviles») y pronkstilleven (que se traduce como «naturalezas de ostentación»). Para designar la pintura de objetos inanimados y las escenas de cocina en España en cambio utilizaban la palabra «bodegón». Fueron los franceses quienes, recién en el siglo XVIII, incorporaron al léxico de las artes visuales la noción de "naturaleza muerta», en concordancia con los sucesos acaecidos en el siglo de las revoluciones y la guillotina. 


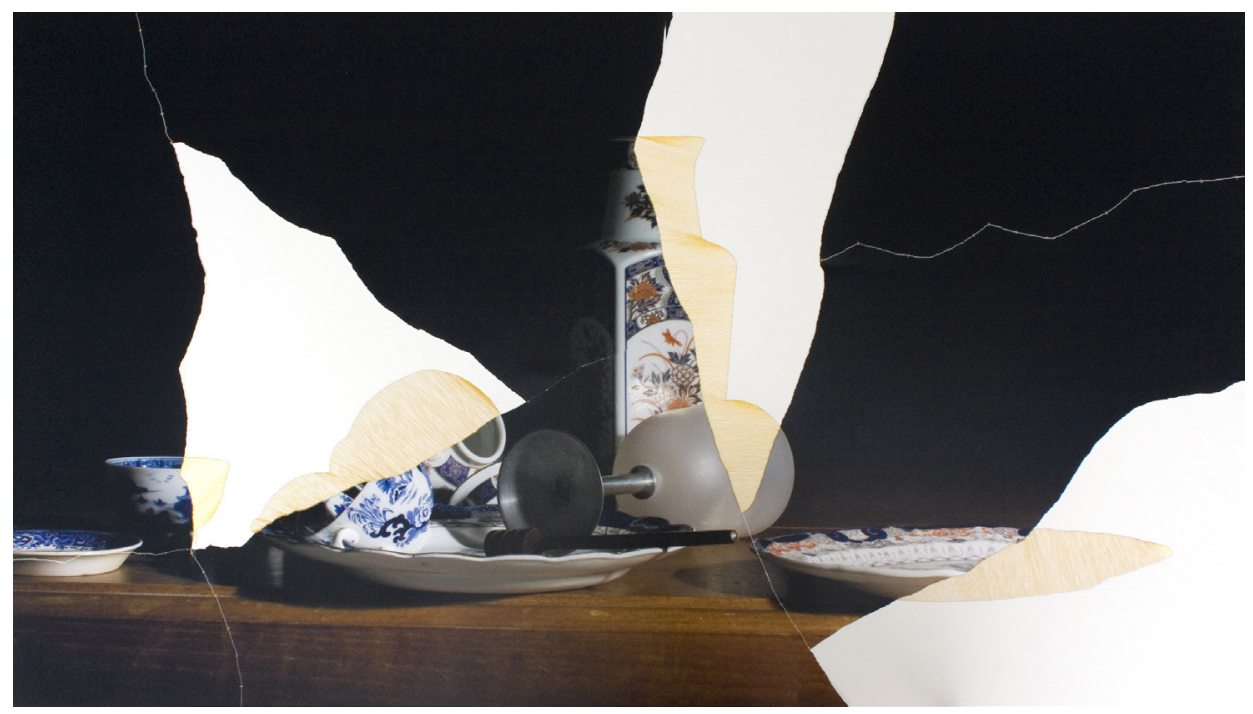

Figura 6. Livia Marin. Nature morte II, 2010. House of Propellers, Londres

Gentileza de Livia Marin

Fotografía: Sachiyo Nishimura

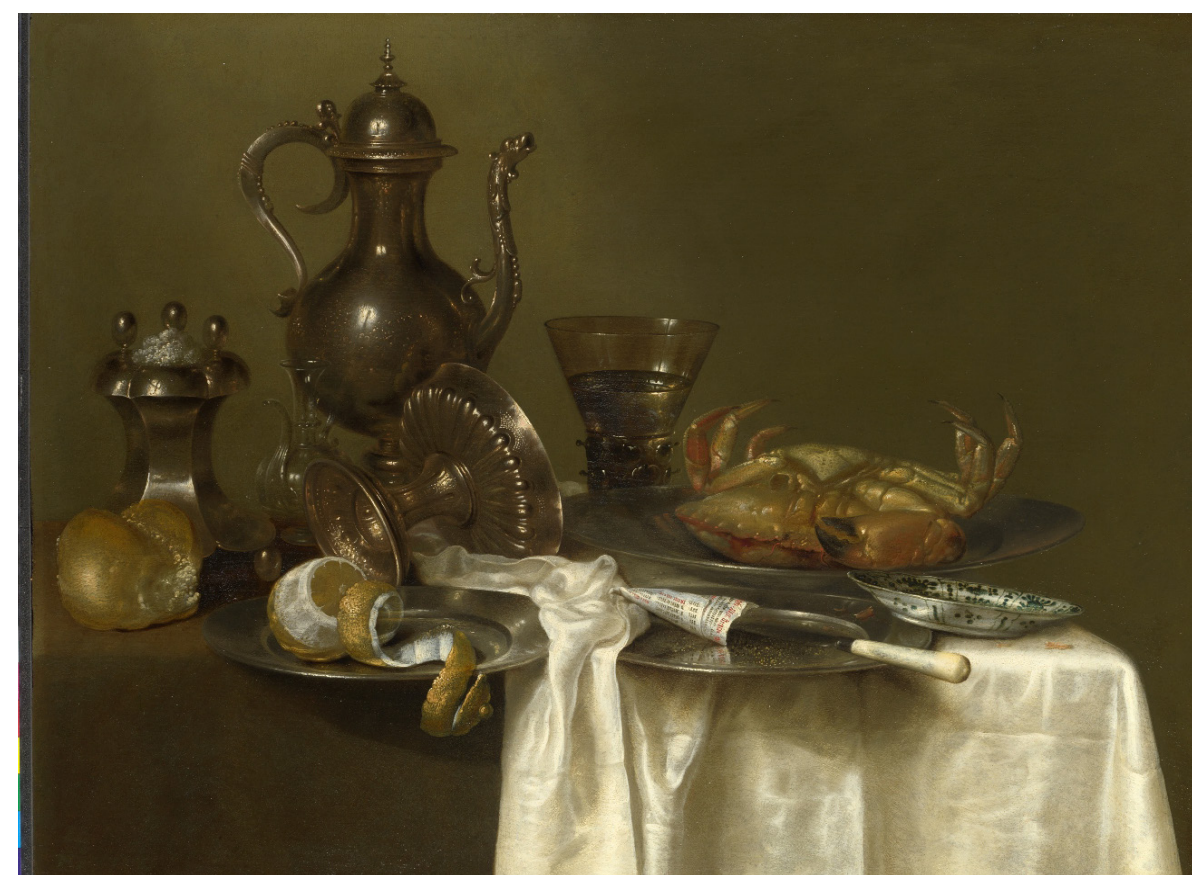

Figura 7. Willem Claesz. HEDA

Naturaleza muerta: Peltre, vasos de plata y cangrejo

Presented by Henry J. Pfungst, 1896

(c) The National Gallery, London. 


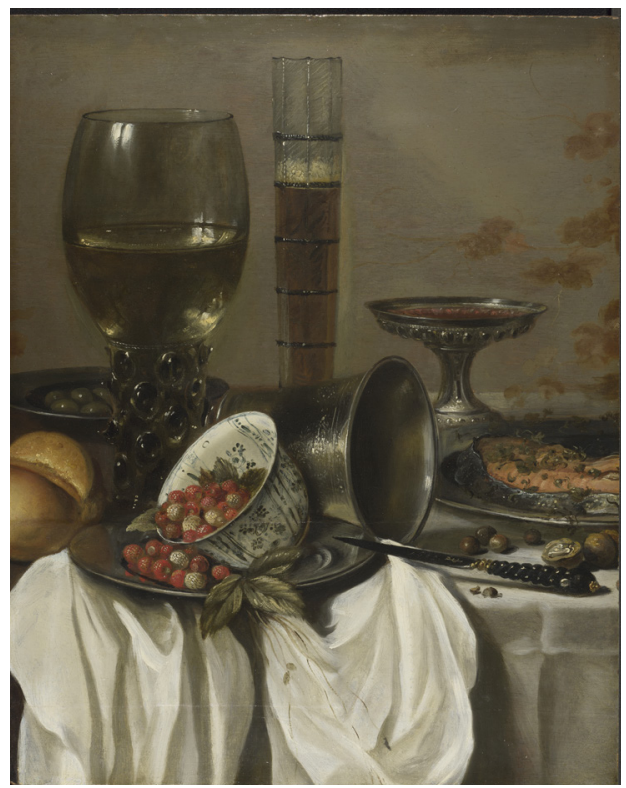

Figura 8. Pieter Claesz

Naturaleza muerta con copas para beber

Salting Bequest, 1910

(c) The National Gallery, London.

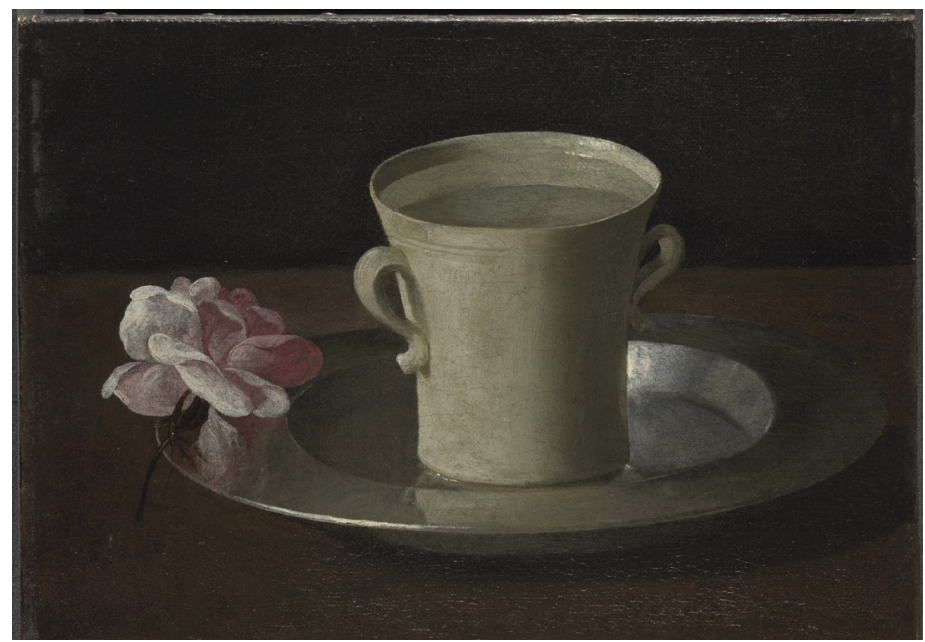

Figura 9. Francisco de Zurbarán.

Taza de agua y rosa.

Bought for the National Gallery by the George Beaumont Group, 1997

(c) The National Gallery, London. 


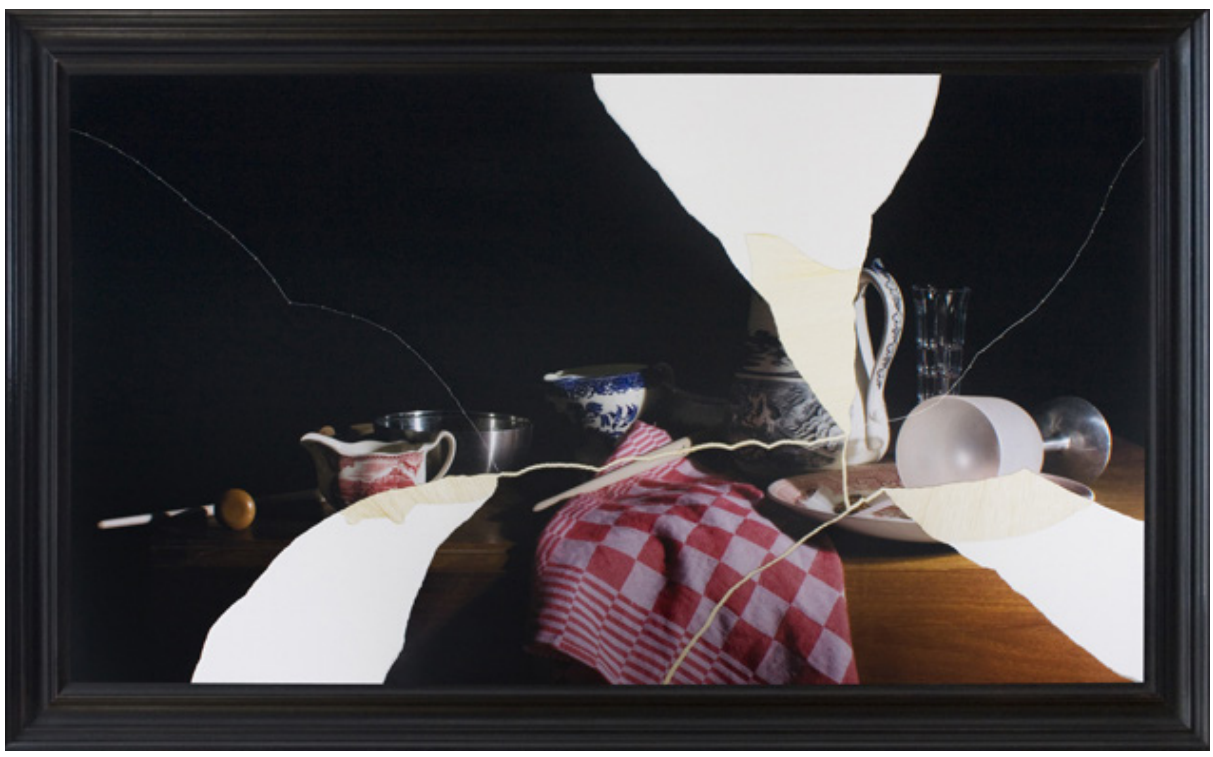

Figura 10. Livia Marin. Nature morte IV, 2010.

Gentileza de Livia Marin. Foto: Sachiyo Nishimura

Consecuente con sus intereses, Livia Marin escogió investigar los códigos de un género que se ocupa primordialmente de los objetos y que históricamente se considera de tono menor; a mediados del siglo xvir la Academia Real de Bellas Artes de París le asignó a la naturaleza muerta el rango más bajo dentro de la escala jerárquica de los géneros pictóricos (Schneider 7; Pevsner 75). Como si fuese a pintar-como antes lo hicieran Willem y Pieter Claesz (Figuras 7 y 8), Willem Kalf, Samuel van Hoogstraten, Cornelius Gijsbrechts o, el mismísimo Francisco de Zurbarán (Figura 9)-, Livia Marin seleccionó y acomodó con sobriedad unos pocos objetos cerámicos de segunda mano sobre una mesa de madera sin mantel. Siguiendo al pie de la letra el esquema barroco, todos ellos se recortaban contra un fondo oscuro. Algunos de los modelos pertenecían a la denominada «colección pobre» de la artista (un plato, un jarrón, un cremero, un bowl), junto a los cuales colocó ya sea una copa, un paño de cocina, una concha y/o algunos utensilios de madera. La siguiente operación consistió en iluminar, según las convenciones pictóricas holandesas, para luego proceder a fotografiar, imprimir, romper la reproducción de lo antes fotografiado y, por último, introducir en su producción de obra el arrepentimiento. Me explico: su acto de creación concluía al juntar los fragmentos de las fotografías que ella misma había roto. Con extraordinaria paciencia y habilidad manual consiguió (re)unir los pedazos, lográndolo, literalmente, al zurcirlos con hilo dorado. El resultado fue un conjunto de trabajos que aparentaban testimoniar visualmente las consecuencias de un día de furia, cuando platos y jarras vuelan por el aire. Lo que se representaba y reproducía en cada una de las obras era la calma después de la tempestad o, si se prefiere, agrupaciones de objetos inertes, nada rimbombantes, sometidos a la poética 
de la fractura, la reparación y el ayuno. La austeridad inundaba «estas mesas» pues no se observaban ni alimentos ni cubiertos. Se trataba de naturalezas muertas que no estaban destinadas a activar el sentido del gusto, sino la vista y el tacto.

En Nature Morte Marin no solo se apropiaba de las pautas preestablecidas de la denominada "cultura de la mesa» (y sus problemas relativos a estructura, composición e iluminación), sino que adoptaba incluso la manera holandesa de enmarcar en el siglo XVII -molduras sobrias y negras hechas en ébano u otras maderas oscuras-. Los trabajos, por ende, se deben analizar con marco incluido, pues estos fueron parte del ejercicio de apropiación (entendiéndose esta como la radicalización del recurso de la cita). A propósito de lo anterior, Deborah David explica que los marcos austeros y oscuros fueron tan populares en los Países Bajos pues se adhirió allí «al protestantismo y los estilos decorativos fueron simplificados en comparación con las aparatosas ornamentaciones propias de los países católicos» (60). Deliberadamente, Livia Marin enmarcó sus obras con listones negros y, al hacerlo, a la vez que parodiaba, provocaba con aquello un contrapunto visual entre el inmaculado contorno y la imagen que este encerraba y contenía, a saber: "cuadros» de naturalezas «rotas», agrupaciones de objetos, en su mayoría de porcelana, que parecían haber sufrido los estragos de una batalla doméstica u otro suceso del cual el espectador no había sido testigo y sobre lo cual solo le era posible especular si acaso las mesas estaban inmortalizadas postriñas, postepisodio telúrico o postcelebración; en la ambigüedad radicaba su atractivo. Sea como fuere, se invitaba a contemplar escenarios sometidos a la fisura y el desgarro, como si hubiesen sido una suerte de ventana rota (Figura 10) que permitía, al igual que en otros trabajos de la artista, evocar territorios creativos pasados, donde la narratividad y cierto dramatismo no estaban del todo ausentes. Estas naturalezas muertas semejaban ventanas que al no estar protegidas por una cortina permitían husmear espacios interiores donde reinaba el desorden, la estrechez económica y la soledad.

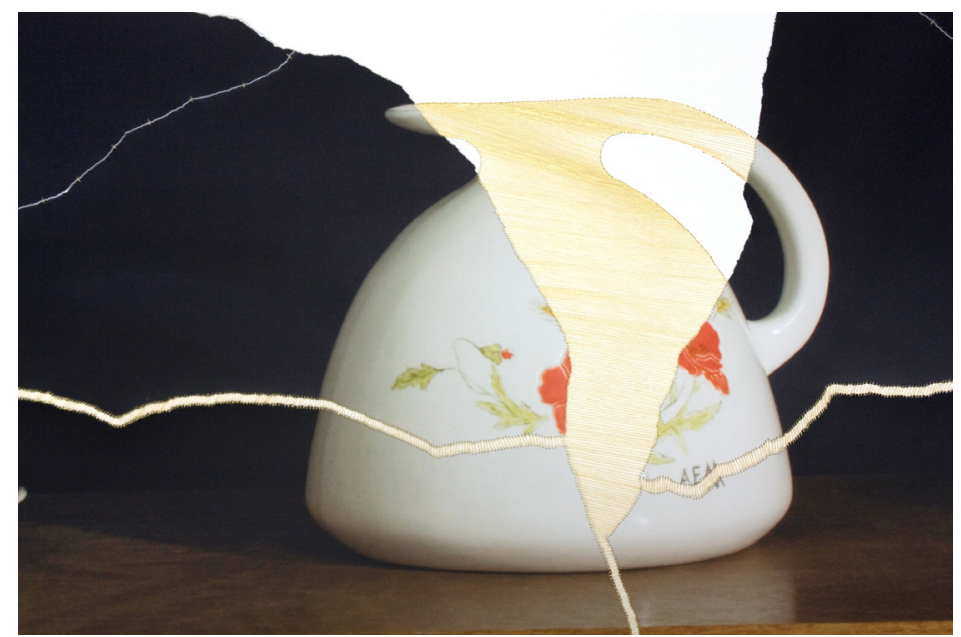

Figura 11. Livia Marin. Detalle Nature morte, 2010. Gentileza de Livia Marin Foto: Sachiyo Nishimura 


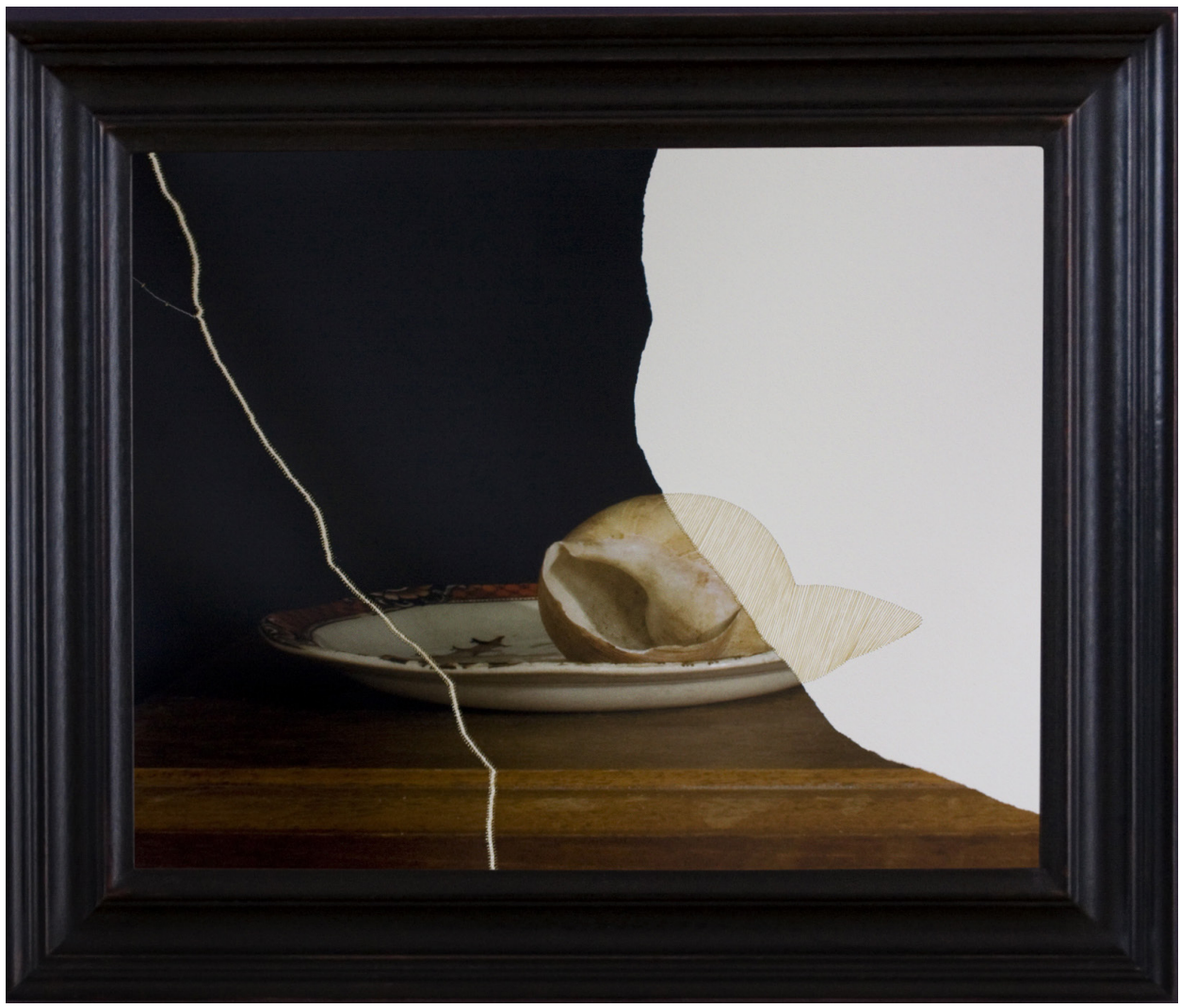

Figura 12. Livia Marin. Nature morte V, 2010.

Gentileza de Livia Marin

Foto: Sachiyo Nishimura

Se invitaba a contemplar una «superficie herida» y, al mismo tiempo, la representación de objetos trizados, pero el acto de reparación (la costura) era tan evidente que negaba la noción de naturaleza «muerta»; la «muerte» de los objetos no llegaba a ocurrir pues las conspicuas suturas se encargaban más bien de enfatizar los aspectos relativos a la restauración y a la conservación. Más que "naturalezas muertas» eran estas «naturalezas heridas», o, si se prefiere, «naturalezas recompuestas». Que quede claro, Marin no fotografió fragmentos de objetos rotos, si estos se visualizaban dañados era por efecto de su operación de rasgadura y reparación en el papel fotográfico. O sea, «la ejecución», «el quiebre» o «el daño» ocurrían en el papel -en la reproducción- y no en el referente. Insisto en que la «muerte» de la naturaleza no llegaba a suceder porque las costuras eran siempre muy obvias e insinuaban una posible (re)compostura ante los ojos del espectador. Además, se podían visualizar como un sutil achurado y/o un bordado que, junto con embellecer la superficie, venía a recuperar formas y contornos perdidos. Si se consideraban las costuras como una hermosa metáfora del recurso de citación, se podían «leer» como un intento por 
«conectar» pasado y presente. Nótese también que las doradas suturas atravesaban la superficie y que al hacerlo generaban movimiento visual (Figura 11), tanto así que atraían a la memoria el desarrollo de una tormenta eléctrica, tornándose de pronto las costuras en rayos. Dicho esto, valga señalar que lo primero en percibirse era un violento enfrentamiento entre zonas oscuras y claras, aunque en una primera mirada los campos blancos (la luz) tendían a cegarnos por unos instantes (no se debe olvidar que los planos de luz avanzan y los de sombra retroceden ópticamente). Al mirar Nature Morte V (Figura 12), por ejemplo, de inmediato se percibía el irregular campo blanco a la derecha del espectador, comenzando a aparecer solo unos segundos después ante nuestros ojos ese solitario plato bajo que nada más contenía una hermosa caracola color miel como extraída de un gabinete de historia natural. A propósito, se podía establecer una relación entre la concha y el territorio íntimo femenino; "por su procedencia acuática, la concha hace presentes los simbolismos propios de este medio: fecundidad, sexo, vida. Su analogía morfológica con el órgano sexual femenino refuerza estos significados» (Revilla 118). Interesantemente, por otra parte, Minguet observa que, en relación a su materialidad, es una «sustancia dura y frágil, como la porcelana» (165). En fin, como en el resto de la serie, en Nature Morte $V$ la visión del total no era inmediata ni simultánea, dosificando Marin la entrega visual: primero nos ofrecía un choque valórico (luz versus sombra), luego una zigzagueante y «tormentosa» gráfica y, por último, una reunión de objetos simples.

Como ocurría en Cosas rotas I y II, en Nature Morte también se percibía un dejo de sentimentalismo, un remedo de la acción materna: me refiero a ese cuidadoso gesto de la madre de la artista quien, posterremoto de 1985, reunió los fragmentos de sus jarrones para después enviarlos a restaurar con el propósito de evitar su pérdida.

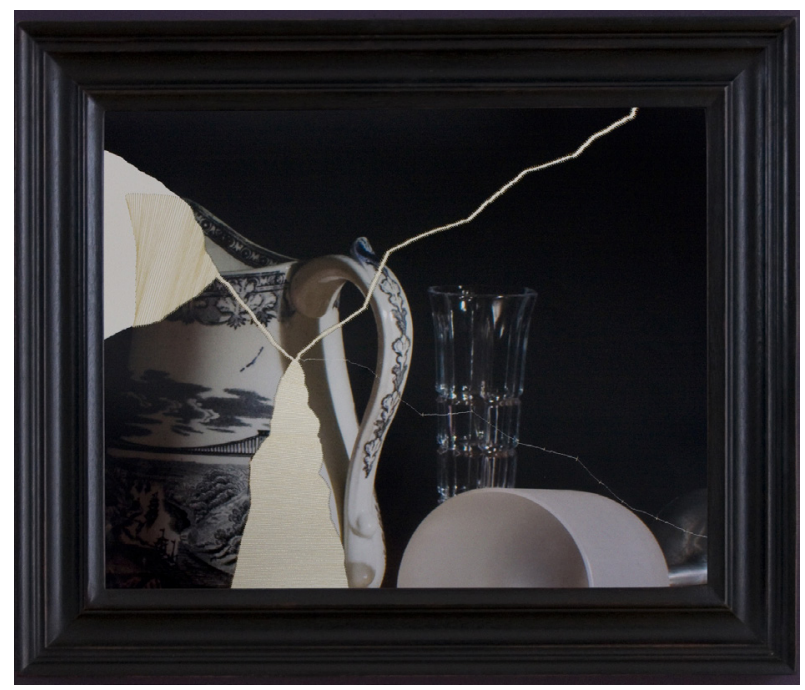

Figura 13. Livia Marin. Nature morte VIII, 2010. Gentileza de Livia Marin Foto:Sachiyo Nishimura 


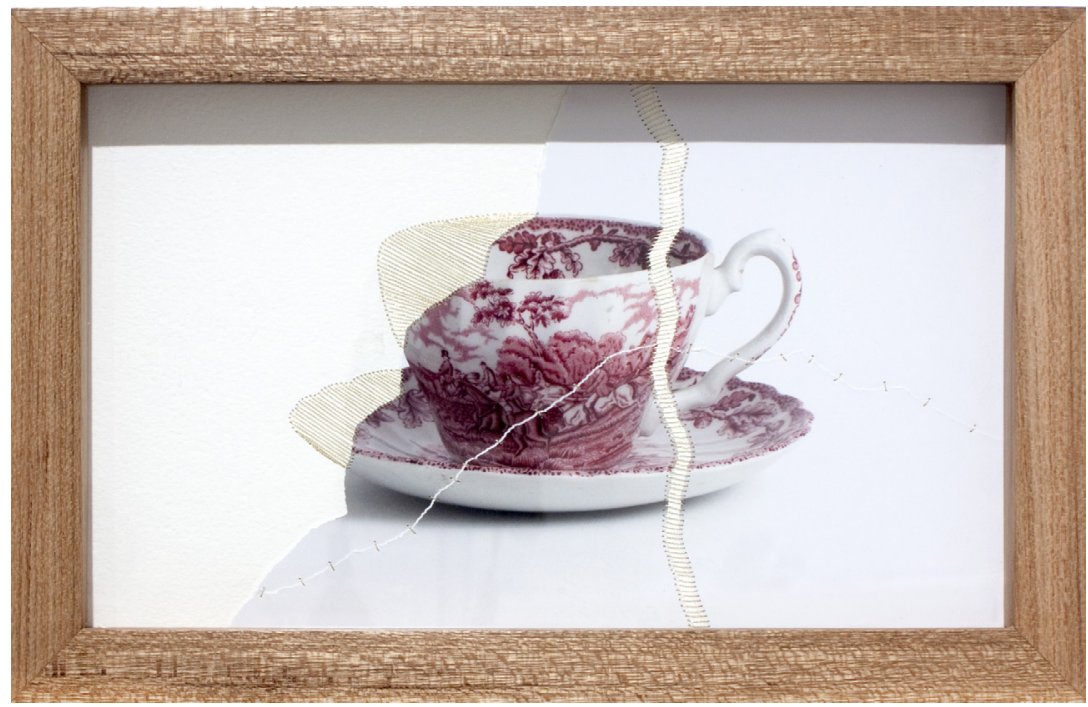

Figura 14. Livia Marin. Sutura, 2011.

Fotografía, hilo de oro, papel, marco de madera

Galeria Eduardo Fernandes, Sao Paulo

Gentileza de Livia Marin

Foto: Livia Marin

Hasta la fecha, siempre se observa en las series de Marin una conducta repetitiva que es necesidad operativa y que al mismo tiempo le permite la construcción de diferencia; Nature morte no era la excepción, tratándose de un conjunto de trabajos similares aunque no idénticos. Los cuadros más pequeños, por ejemplo, eran detalles de las cuatro fotografías de mayor formato (Figura 13), en una pequeña transgresión a los códigos de las naturalezas muertas del barroco, al no ocurrir en estas el close-up; las tomas de acercamiento son más propias de nuestra época donde la tecnología permite, sin ninguna dificultad, hacer zoom según la curiosidad o el estado de la visión del usuario.

Mientras en su serie Nature Morte la artista se concentraba en fotografiar agrupaciones de objetos sin necesariamente indicar jerarquías, en Sutura, al año siguiente, reunió tres series del proyecto Broken Things: las esculturas, algunas piezas de sus naturalezas muertas y el trabajo fotográfico de objetos aislados donde redujo los formatos $(30$ x $40 \mathrm{~cm}$ y 15 x 28,5 cm) subrayando que menos es más. Reservó entonces el primer plano para un único y solitario objeto (una tetera, un plato de pan) o para el inseparable dúo compuesto por la taza de té y su respectivo plato, a lo más (Figura 14). El nombre de la muestra fue un acierto, pues el término «sutura» pertenece al léxico médico y se refiere al acto de juntar tejidos después de haber sufrido estos un leve o gran trauma; nótese que Marin enseñaba un objeto «herido» y «suturado» recortándose contra un aséptico fondo blanco. Proponía al espectador visualizar así la condición precaria de una determinada pieza de porcelana y, más 
aún, simulaba su obra ser un registro fotográfico que inmortalizaba el proceso de restauración de un objeto. Ahora bien, los objetos solitarios y trizados no tenían en absoluto aspecto de "pieza única» digna de colección y de reparación; por mucho que estuviesen enmarcados, no convencían como objeto-reliquia. Conmovedor el apego de Marin por esas teteras, por esas tazas y platos que son parte de nuestra rutina, encomiable su empeño por invitarnos a examinarlos con atención, aunque solo fuese por unos segundos.

Ambas series comentaban «en voz baja» - «en tono menor»- sobre nuestra sociedad constantemente ocupada del consumo, del valor y de la distribución de cosas. En Nature Morte y Sutura se observaba así una puesta en valor tanto del objeto cotidiano como del propio «objeto-cuadro». Todos los trabajos bidimensionales se alineaban con la larga tradición pictórica que propone al espectador reflexionar acerca de la permanencia, la fragilidad y la belleza de toda producción humana. Las obras que articulaba Marin eran cuadros de vanidades que, de un modo u otro, hacían referencia a todas aquellas naturalezas muertas (vanitas) donde se alude a lo perecedero, a «la transitoria naturaleza de la vida» (Prada 45). No es casualidad que en Nature Morte II y IV (Figuras 6 y 10), por ejemplo, colocase Marin una copa caída, sabiendo bien que, al igual que una calavera, un espejo o una vela apagada, es este un símbolo de caducidad.

\section{CONCLUSIÓN}

$\mathrm{Al}$ principio de este escrito expliqué que Livia Marin era una artista nómade, aunque en ese momento desconocía que preparaba una muestra titulada Nomad patterns (Patrones nómades), su tercera exposición individual en Londres, inaugurada el 6 junio de 2012. Se trata de una instalación donde interviene el espacio de una galería (Eagle Gallery EMH Arts) con aproximadamente cuarenta «objetos-derretidos». Esta es una continuación de la investigación que iniciara el 2009 con Cosas rotas II, lo cual significa que no ha parado de adquirir porcelanas y cerámicas en diversos mercados de segunda mano y/o en importadoras de objetos manufacturados en Asia. Sigue concentrada en un ejercicio de apropiación-transformación objetual, poniendo, todavía, a prueba la integridad funcional de la loza: aquella que ya existe, que ya está construida y a la cual ya se le ha asignado una función y una posición en el hacer cotidiano. Por lo visto, la artista seguirá por un buen rato preocupada de entender la vida de los objetos e intentando cambiar sus formas, aquellas que nos son tan familiares, para nuestro deleite y reflexión.

En Livia Marin «habita» la figura del artista y del artesano, del coleccionista y del hacedor de objetos, siendo sus predilectos aquellos que «oscilan entre lo necesario y lo prescindible» (Marin «El objeto y su manifestación» 71). En agosto de 2002 bautizó su muestra individual en galería Animal (Santiago, Chile) como El objeto y su manifestación; pero la verdad es que es ella quien se manifiesta a través de los objetos. En todas las obras analizadas queda en evidencia: 1) su obsesión por los artículos pequeños, de 
bajo costo, que se venden en grandes cantidades y que por su cotidianeidad resultan imperceptibles (por algo la muestra de Gasco se titulaba El lugar de lo invisible); 2) su entusiasmo por la adulteración de piezas y diseños estandarizados, es decir, por la intervención artística del objeto común y/o por la apropiación-transformación objetual; 3) su reciente fascinación por los códigos de la naturaleza muerta del barroco holandés y; 4) su disposición a indagar acerca de la pérdida de identidades culturales. En todas sus últimas exposiciones utiliza ex professo el diseño que Thomas Minton creara en el siglo XVIII para ser aplicado sobre la vajilla de la aristocracia inglesa, reconociendo en aquel un híbrido cuyos territorios creativos pasados y presentes son ahora difusos; el famoso Blue Willow no pertenece ya ni a Minton ni a Marin, no representa ni a la cerámica oriental ni a la occidental, convertido hoy en la esencia del lugar común.

\section{REFERENCIAS}

Campaña, Claudia. Sobre la representación de objetos naturales y culturales en naturaleza muerta. Artistas chilenos. Santiago: Morgan Impresores, 2002. Medio impreso.

David, Deborah. The Secret Lives of Frames: One Hundred Years of Art and Artistry. Nueva York: Filipacchi Publishing, 2007. Medio impreso.

Ebert-Schifferer, Sybille. Still life. A History. New York: Abrams, 1999. Medio impreso. Jackson, Anna y Amin Jaffer, eds. Encounters. The meeting of Asia and Europe 15001800. Londres: V\&A Publications, 2004. Medio impreso.

Jarque, Fietta. «El minimalismo 'infectado’ de Mona Hatoum». El País 14 de octubre de 2010. Fecha de ingreso: 8 de enero de 2012. Sitio web.

Marin, Livia. «El objeto y su manifestación». Memoria 2002 Galería Animal. Santiago: G2 Chile, 2002, 67-71. Medio impreso.

---. En torno a «cosas rotas». Esteka 12 (2012). 16-7. Medio impreso.

Minguet, Phillipe. Estética del rococó. Madrid: Cátedra, 1992. Medio impreso.

Morphet, Richard y Robert Rosemblum. Encounters. New Art from the Old. Londres: National Gallery Company, 2000. Medio impreso.

Pevsner, Nikolaus. Las academias de arte: pasado, presente. Madrid: Cátedra, 1982. Medio impreso.

Portanova, Joseph. «Porcelaine, The Willow Pattern and Chinoserie». Fecha de ingreso: 2 de febrero de 2012. Sitio web.

Prada, Juan Martín. La apropiación posmoderna: arte, práctica apropiacionista y teoría de la posmodernidad. Caracas: Fundamentos, 2009. Medio impreso.

Revilla, Federico. Diccionario de iconografía y simbología. Cátedra: Madrid, 2003. Medio impreso.

Schneider, Norbert. Naturaleza muerta. Apariencia real y sentido alegórico de las cosas. La naturaleza muerta en la Edad Moderna temprana. Colonia: Taschen, 1992. Medio impreso.

Woodford, Susan. Cómo mirar un cuadro. Barcelona: Gustavo Gili, 2011. Medio impreso. 